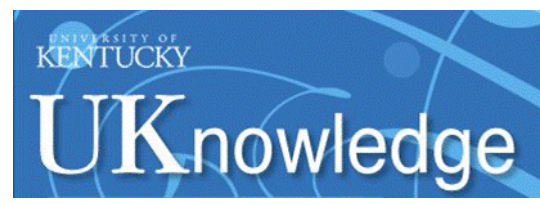

University of Kentucky

UKnowledge

$10-2015$

\title{
Translating Neuroscience Research to Oral Medicine: Oxytocin and Human Behavior
}

David A. Nash

University of Kentucky, danash@uky.edu

Follow this and additional works at: https://uknowledge.uky.edu/ohs_facpub

Part of the Dentistry Commons

Right click to open a feedback form in a new tab to let us know how this document benefits you.

\section{Repository Citation}

Nash, David A., "Translating Neuroscience Research to Oral Medicine: Oxytocin and Human Behavior" (2015). Oral Health Science Faculty Publications. 5.

https://uknowledge.uky.edu/ohs_facpub/5

This Letter to the Editor is brought to you for free and open access by the Oral Health Science at UKnowledge. It has been accepted for inclusion in Oral Health Science Faculty Publications by an authorized administrator of UKnowledge. For more information, please contact UKnowledge@lsv.uky.edu. 


\title{
Translating Neuroscience Research to Oral Medicine: Oxytocin and Human Behavior
}

\author{
Digital Object Identifier (DOI) \\ http://dx.doi.org/10.1111/odi.12359
}

Notes/Citation Information

Published in Oral Diseases, v. 21, no. 7, p. 913-917.

(C) 2015 John Wiley \& Sons A/S. Published by John Wiley \& Sons Ltd

This is the peer reviewed version of the following article: Nash, D. A. (2015), Translating Neuroscience Research to Oral Medicine: Oxytocin and Human Behavior. Oral Diseases, 21: 913-917, which has been published in final form at http://dx.doi.org/10.1111/odi.12359. This article may be used for noncommercial purposes in accordance with Wiley Terms and Conditions for Self-Archiving.

This letter to the editor is available at UKnowledge: https://uknowledge.uky.edu/ohs_facpub/5 
This is the peer reviewed version of the following article: Nash, D. A. (2015), Translating Neuroscience Research to Oral Medicine: Oxytocin and Human Behavior. Oral Diseases, 21: 913-917, which has been published in final form at http://dx.doi.org/10.1111/odi.12359. This article may be used for non-commercial purposes in accordance with Wiley Terms and Conditions for Self-Archiving. 


\title{
Translating Neuroscience Research to Oral Medicine: Oxytocin and Human Behavior
}

\author{
David A. Nash, D.M.D., M.S., Ed.D. \\ William R. Willard Professor of Dental Education \\ Professor of Pediatric Dentistry \\ College of Dentistry \\ University of Kentucky \\ Lexington, Kentucky \\ Email: danash@email.uky.edu
}

Key Words: Translational Science, Neuroscience, Oxytocin, Human Behavior, Epigenetics, Research in Oral Medicine 
The neuropeptide oxytocin is known in mammalian species to facilitate uterine contractions during birth as well as to play a role in the release of milk; however, research has now demonstrated that oxytocin modulates a variety of behaviors in addition to its functions associated with birth and lactation. It is basic to prosocial behavior; is critical to social attachment and affiliation; bonds mother and child; reduces stress-related behaviors and anxiety; increases pain tolerance; increases trust; increases emotional empathy; promotes cooperation, is associated with "falling in love," and accompanies sexual desire and orgasm. One prominent researcher in the field has designated oxytocin as the "moral molecule" based on its role in emotional empathy, trust, generosity, and cooperative behavior (Zak, 2012). Oxytocin has been called the "great facilitator of life" (Lee et al., 2009).

Given the broad range of effects oxytocin has on social behavior the question emerges as to what role oxytocin may play in behaviors associated with oral health care. While there has been an extraordinary proliferation of research relating oxytocin to humans, no studies have been identified relating oxytocin to behavioral issues associated with the seeking or provision of oral health care. A review of the neurobiology of the oxytocin system and its effect on human behavior, including psychosocial dysfunctions, suggests opportunities for research in oral medicine.

\section{Neurobiology of Oxytocin}

Oxytocin is synthesized in the hypothalamus and stored in the pituitary until released into the peripheral circulation. Because of the blood/brain barrier, oxytocin secreted from the pituitary cannot reenter the brain. Oxytocin receptors in the body are widespread and include the heart, uterus, testes and regions of the spinal cord that regulate the autonomic nervous system. (While no oxytocin receptors have as of yet been identified in the mouth, there is currently a research effort at Columbia University to identify oxytocin receptors in the mouth and eyes in the context of using a combination of oxytocin and secretin to treat dry eyes and dry mouth; Welch 2015). The hypothalamus also releases oxytocin directly in the brain where it acts as a neurotransmitter, coordinating a large number of physiological processes that affect behavior. Thus oxytocin has endogenous effects on neurotransmission within the brain and exogenous effects systemically as a hormone secreted from the pituitary gland.

Only one oxytocin receptor gene, OXTR, has been identified; it is a G-protein linked receptor (Gimpl and Fahrenholz, 2001). There are three known OXTR polymorphisms: G(Guanine) G, A(Adenine) G, and AA, reflecting the allelic nucleotides present in the gene. These small genetic differences result in differing effects on human behavior. For example, individuals with the GG allele have higher levels of circulating oxytocin. Consequently, these individuals more strongly reflect the prosocial behaviors associated with oxytocin versus those with the AG and AA types (Rodrigues et al., 2009). While genomic information is transmitted to offspring from parental generations, recent evidence indicates that epigenetic mechanisms are capable of mediating this transmission (Kumsta et al., 2013). Epigenetics refers to changes in gene function unrelated to changes 
in DNA sequence. DNA methylation is one epigenetic mechanism by which cells can control transcription through modifications of the target gene. Greater methylation of the DNA reduces the expression of the gene (Jack et al., 2012). Behavioral neuroscientists now understand epigenetics as a biological mechanism in which environmental influences result in changes in physiology and thus behavior; "nurture's effect on nature." Epigenetics has been characterized as the "new frontier in neuroendocrinology" (McCarty and Cruz, 2008).

Oxytocin is uniquely found in all mammalian species - social animals, living and reproducing in pairs or groups (Carter, 1998). The hormone has had a major role from deep in evolutionary history of promoting mammals to seek a range of mating partners; to prefer specific partners; and to attach to a partner long enough to accomplish parenting duties that permit the survival of offspring (Fisher et al., 2006). Animal studies provide evidence that the quality of maternal behavior early in life has an epigenetic effect on the development of OXTR receptors. In rodent models, the licking/grooming behavior of the dam has been demonstrated to have this epigenetic effect resulting in offspring exhibiting less stress-related behaviors and more sociability (Weaver, 2007). Differential early handling experiences in prairie voles is associated with long-term social attachment behaviors, as well as anxiety-reduced behaviors related to oxytocin (Carter, 2003; Bales et al., 2011). Oxytocin plays a key role in maintaining social relationships in chimpanzees beyond genetic relationships, with cooperative relationships in social grooming facilitated by oxytocin (Crockford et al., 2013). Oxytocin has been demonstrated to have a reliable effect of increasing pain tolerance in 20 of 33 animal studies reviewed (Rash, 2014).

\section{Oxytocin and Human Behavior}

Oxytocin is basic to human reproduction (Carter, 1990 and 2014). As indicated, oxytocin is associated with the bonding between mother and child. Cuddling/touching of the child by the mother has a significant impact on oxytocin release (Carter, 1998; Strathearn, 2011). Additionally, in the early stages of infant development, such cuddling is thought to increase the development of OXTR receptors (Fleming et al., 2002; Keverne and Curley, 2008). In general, oxytocin acts to permit the high levels of social sensitivity and attunement necessary for human sociality and for maternal care-giving (Carter, 2003; Francis et al., 2002).

The evolution and survival of Homo sapiens has been facilitated by social intelligence and social communication (Hrdy, 2009). Survival and reproduction depend on adapting social and reproductive behavior to environmental and social demands (Carter, 1998). Humans' large cortex, high levels of social recognition, and complex social interactions could not have evolved without the physiological and behavioral function of oxytocin (Carter, 2014). Oxytocin has the opposite effect on behavior from the "fight or flight' hormones vasopressin and adrenaline, which increase stress, danger-readiness, and wariness of strangers. Oxytocin reduces anxiety and stress, increases the pain threshold, reduces depression, and enables the body to relax (Uvnäs-Moberg, 2003). 
Zak and colleagues published the first study to suggest that oxytocin in humans was related to social behavior, thus consistent with animal studies (Zak et al. 2004). Investigators demonstrated that in an exchange of money requiring reciprocity, trusting behavior in the exchange was associated with higher levels of circulating oxytocin.

Individuals with AG/AA alleles of the OXTR gene display higher physiological and dispositional stress reactivity. (Rodrigues et al., 2009) Impaired oxytocin signaling may be a biomarker of anxiety in humans, and a potential target for therapeutic development in individuals with anxiety disorders (Carson et al., 2014). Human touch increases circulating oxytocin thus reducing stress and promoting self-soothing (Champagne and Rissman, 2011; Ellingsen et al., 2014; Uvnas-Moberg et al., 2015).

Empathy developed in neuroevolution in the context of parental care in mammalians and the neurobiological mechanisms associated with oxytocin that underlie its operation (Carter et al., 2009; Decety, 2011). Compared to individuals homozygous for the G allele (GG), AG/AA individuals exhibit lower behavioral and dispositional empathy. (Rodriques, 2009) A number of studies have documented the relationship of oxytocin to empathy (Fesser et al., 2015; Luo et al., 2015; Uzefovsky et al., 2015).

Epigenetic regulation of the OXTR receptor gene through methylation appears to play a critical role in social attachment and social cognition, as well as anxiety and stress related behaviors (Kumsta et al., 2012; Ziegler et al., 2015). Early abuse of females results in decreased oxytocin levels in comparison to females without such abuse (Heim et al., 2009; Champagne and Rissman, 2011). Evidence also suggests the developing oxytocin system is significantly impaired in children reared in institutions associated with severely depriving conditions, compared to children reared in a typical home environment (Wismer Fries et al., 2005; Champagne and Rissman, 2011). A retrospective, self-report assessment of maternal care suggests the transmission of parental bonding style across generations, independent of socio-economic status, maternal or daughter temperament (Miller et al., 1997; Champagne, 2008; Dias et al. 2015). A mother's own attachment to her mother is a good predictor of her infant's attachment to her; most likely the result of the epigenetic impact on OXYR receptors (Fleming et al. 2002). Maternal neglect, both physical and emotional is a pervasive public health challenge with serious long term effects on child development (Strathearn, 2011).

Research suggests that oxytocin deficits may play a role in psycho-social dysfunctions including autism (Andare et al., 2010; Chen and Johnson, 2012), borderline personality disorders (Simeon et al., 2011), social anxiety disorder/fear (Guastella et al., 2009; Labuschagne et al., 2010), and callous-emotional behavior and conduct problems in adolescents (Dadds et al., 2014). Adolescent boys with significant conduct problems and exhibiting callous-unemotional traits exhibit high levels of methylation of the OXTR gene lowering circulating oxytocin and resulting in the functional impairment of empathy (Cecil et al., 2014). Aspects of psycho-social pathology may be informed by further understanding of the epigenetic process and its functional significance (Dadds et al., 2014). 


\section{The Therapeutic Use of Intra-nasal Administered Oxytocin}

Research on the association of oxytocin with multiple prosocial behaviors has led to experimental studies on the effect of administering oxytocin to humans (Guastella et al., 2013). Oxytocin does not pass the blood-brain barrier when administered intravenously, and is destroyed in the gastrointestinal tract. However, neuropeptides do cross the bloodbrain barrier when administered intra-nasally (Born et al., 2002). Intranasal oxytocin has a duration of effect of 2-4 hours (Huffmeijer et al., 2012). In a seminal study published in Nature, Kosfeld and colleagues analyzed the effect of exogenously administered oxytocin on individuals' decision in a trust game with tangible monetary risks at stake (Kosfeld et al., 2005). Participants in the study were administered 24 IU oxytocin (Syntocinon spray) or a placebo 50 minutes before the start of the trust experiment. The results indicated that oxytocin specifically affected trust in interpersonal interactions.

A critical review of the influence of oxytocin nasal spray in humans concluded that oxytocin nasal spray impressively impacts social and behavioral processes (Guastella and McLeod, 2012). These include reductions in fear and anxiety in social situations, the facilitation of reward cues during social contact, and the enhancement of social salience to enable more effective responses to social information. Intranasal oxytocin has been demonstrated to improve therapy for social anxiety disorder (Guastella et al., 2009). Intranasal administration of oxytocin augments endogenous pain inhibitory capacity and reduces negative mood states, including anxiety (Goodin et al., 2014). Both animal and human research has found that intranasal oxytocin administration lowered pain perception (Rash et al. 2014). Intranasal oxytocin attenuates the fear response (Puglia et al., 2015; Koch et al., 2014; Acheson et al., 2013). Empathy is increased after intranasal oxytocin administration (Hurlemann et al., 2010; Simeon et al., 2011). There is a potential therapeutic role for intranasal administration of oxytocin in children on the autism spectrum (Andari et al., 2010; Carter, 2007; Gregory et al., 2009; Guastella et al., 2012 and 2014; Jacob et al., 2007). Intranasal oxytocin has also been investigated in individuals with borderline personality disorder (Simeon et al., 2011). A magnetic resonance imaging experiment found that oxytocin administered intra-nasally acts to limit the control of the amygdala while simultaneously augmenting the medial prefrontal cortex function to facilitate the extinction of conditioned fear (Eckstein et al. 2014).

\section{Research Potentials for Oral Medicine}

Oxytocin is receiving increasing attention in behavioral research due to its promotion of social behavior and its regulation of stress, anxiety, fear, and pain tolerance, all factors affecting oral health care. Additionally, it is has been demonstrated to modulate emotional empathy, trust, as well as to be responsive to touch. Endogenous oxytocin can be measured non-invasively through urinary levels or salivary samples (Crockford et al. 2014). Such a non-invasive assessment can be related to a number of behavioral variables of interest in oral medicine, including the therapeutic use of intranasal oxytocin. 
Maternal anxiety has been identified as contributor to the uncooperative behavior of children in the dental environment (Johnson and Baldwin, 1968). As stated previously, the early bonding relationship between mother and child affects the child's behavior through epigenetic effects on the oxytocin system. Studies of mothers' anxiety and oxytocin levels in relationship to their children's anxiety, oxytocin levels, and behavior in receiving dental care could assist in understanding cooperation of children in the dental setting. Mothers with reduced oxytocin receptors and circulating oxytocin would be hypothesized to provide lower levels of empathic bonding with their children and thus would have more anxious children. As previously indicated, epigenetic mechanisms cross generations, with an effect of grandmother to mother to child (Miller et al. 1997; Champagne, 2008; Dias et al. 2015).

The administration of intranasal oxytocin could have a role in reducing anxiety in adults and improving cooperative behavior in children when receiving dental care.

Administration of oxytocin could facilitate the extinction of conditioned fear; or enhance empathy and/or trust. A more focused role for the therapeutic use of oxytocin may be a potential in children whose history includes autism, or psycho-social problems such as callous-emotional traits or misconduct.

Human touch results in a spike in oxytocin levels resulting in a reduction in stress reactivity (Uvnas-Moberg et al. 2015). Touch could play a role in reducing anxiety in dental care. One study demonstrates a positive relationship between touch and children's cooperative behavior (Greenbaum et al. 1990). Research is necessary to understand the relationship of touch to a reduction in anxiety/stress reactivity and to oxytocin levels when receiving oral health care.

Empathy, both intellectual and emotional, is an important personality characteristic for individuals in the health professions (Nash, 2010). Oxytocin is understood to be the "empathy hormone," essential to building trust. Because of the power differential existing between dentist and patient, a critical dimension of the professional relationship is the trust the patient has for the dentist. Studies of oxytocin levels in patients relative to the trust they have for their dentist may enlarge understandings of the dentist/patient relationship.

\section{Conclusion}

Neuroscience is helping explicate the foundations for many aspects of human behavior. Translating basic neuroscience research on the relationship of the oxytocin system to human behavior offers significant opportunity for behavioral and other research in oral medicine; research with the potential to improve the delivery of oral health care. 


\section{References}

Acheson D, Feifel D, de Wilde S, McKinney R. Lohr J, Risbrough V (2013). The effect of intranasal oxytocin on conditioned fear extinction and rell in a health human sample. Psychopharmacology 229(1):199-208.

Andari E, Duhamel JF, Zalla T, Herbrecht E, Leboyer M, Sirigu A (2010). Promoting social behavior with oxytocin in high functioning autism spectrum disorders. Proc Natl Acad Sci USA 107(9):4389-4394.

Bales KL, Boone E, Epperson P, Hoffman G, Carter CS (2011). Are behavioral effects of early experience mediated by oxytocin? Front Psychiatry 2:24.

Born J, Lange T, Kern W, McGregor GP, Bickel U, Fehm HL (2002). Sniffing neuropeptides: a transnasal approach to the human brain. Nat Neurosci 5(6):514-516.

Carson DS, Berquist SW, Trujillo TH, Garner JP, Hannah Sl, Hyde AS, Sumiyoshi RD, Jackson LP, Moss JK, Strehlow MC, et al. (2014). Cerebrospinal fluid and plasma oxytocin concentrations are positively correlated and negatively predict anxiety in children. Mol Psychiatry Nov 4; Epub released ahead of print.

Carter CS (1990). Oxytocin and sexual behavior. Neurosci Biobehav Rev 16(2):133-144.

Carter CS (1998). Neuroendocrine perspectives on social attachment and love.

Psychoneuroendocrinology 23(8):779-818.

Carter CS (2003). Developmental consequences of oxytocin. Physiol Behav 79(3):383397.

Carter CS, Harris J, Porges SW (2009). Neural and evolutionary perspectives on empathy. In The Social Neuroscience of Empathy. J. Decety and W. Ickes, Eds.:169-182. MIT Press. Cambridge.

Carter CS (2014). Oxytocin pathways and the evolution of human behavior. Annu. Rev Psychol 65:17-39.

Carter S (2007). Sex differences in oxytocin and vasopressin: implications for autism spectrum disorders? Behav Brain Res 176(1):170-186.

Cecil CAM, Lysenko LJ, Jaffee SR, Pingault JB, Smith RG, Relton CI, Woodward G, McArdle W, Mill J, Barker ED (2014). Environmental risk, oxytocin receptor gene (OXTR) methylation and youth callous-unemotional traits: a 13 year longitudinal study. Mol Psychiatry 19:1071-1077.

Champagne FA (2008). Epigenetic mechanisms and transgenerational effects of maternal care. Front Neuroendocrinol 29(3):386-397. 
Champagne, FA, Rissman EG (2011). Behavioral Epigenetics: a new frontier in the study of hormones and behavior. Horm Behav 59(3):277-278.

Chen FS, Johnson SC (2012). An oxytocin receptor gene variant predicts attachment anxiety in females an autism spectrum traits in males. Soc Psychol Personal 3:93-99.

Crockford C, Deschner T, Ziegler TE, Wittig RM (2014). Endogenous peripheral oxytocin measures can give insight into the dynamics of social relationships: a review. Front Behav Neurosci 8:68.

Crockford C, Wittig K. Langergraber T, Ziegler TE, Zuberbuhler T. Deschner T (2013). Urinary oxytocin and social bonding in related and unrelated wild chimpanzees. Proc Royal Soc B: BS 280(1755).

Dadds MR, MacDonald E, Cauchi A, Williams K, Levy F, Brennan J (2014). Nasal oxytocin for social deficits in childhood autism: a randomized controlled trial. J Autism Dev Disord 44(3);521-531.

Dadds MR, Moul C, Cauchi A, Dobson-Stone C, Hawes DJ, Brennan J, Ebsten RE (2014). Methylation of the oxytocin receptor gene and oxytocin blood levels in the development of psychopathy. Dev Psychopathol 26(1):21-31.

Decety J (2011). The neuroevolution of empathy. Ann N Y Acad Sci. 1231:35-45. $\mathrm{Du}$ Vigneaud V, Ressler C, Trippett $\mathrm{S}$. The sequence of amino acids in oxytocin, with a proposal for the structure of oxytocin. J Biol Chem 205:949-957.

Dias BG, Maddox SA, Klengel T, Ressler KJ (2015). Epigenetic mechanisms underlying learning and the inheritance of learned behaviors. Trends Neurosci 38(2):96-107.

Eckstein M, Becker B, Scheele D, Scholz C. Preckel K, Schlaepfer TE, Grinevich V, Kendrick KM, Maier W, Hurlemann R (2014). Oxytocin facilitates the extinction of conditioned fear in humans. Biol Psychiatry. October 13; Epub ahead of print.

Ellingsen DM, Wessberg J, Chelnokova O, Olausson H, Laeng B, Leknes S (2014). In touch with your emotion: oxytocin and touch change social impression while others facial expression can alter touch. Psychoneuroendocrinology 39:11-20.

Feeser M, Fan Y, Weigand A, Hahn A, Gärtner M, Böker H, Grimm S, Bajbouj M (2015). Oxytocin improves mentalizing - pronounced effects for individuals with attenuated ability to empathize. Psychoneuroendocrinology 53:223-32.

Fisher HE, Aron A, Brown LL (2006). Romantic love: a mammalian brain system for mate choice. Philos Trans R Soc Lond B: Bio Sci 29;361(1476):2173-2186. 
Fleming AS, Kraemer GW, Gonzalez A. Lovic V, Rees S, Melo A (2002). Mothering begets mothering: the transmission of behavior and its neurobiology across generations. Pharmacol Biochem Behav 73(1):61-75.

Frances DD, Young LJ, Meaney MJ, Insel TR (2002). Naturally occurring differences in maternal care are associated with the expression of oxytocin and vasopressin receptors: gender differences. J Neuroendocrinol. 14:349-353.

Gimpl G, Fahrenholz F (2001). The oxytocin receptor system: structure, function, and regulation. Physiol Rev 81(2):629-683.

Goodin, BR, Anderson AJ, Freeman EL, Bulls HW, Robbins, MT, Ness, TJ (2014). Intranasal oxytocin administration is associated with enhanced endogenous pain inhibition and reduced negative mood states. Clin J Pain Nov 3 Epub ahead of print.

Greenbaum PE, Lumley MA, Turner C, Melamed BG (1993). Dentist's reassuring touch: effects on children's behavior. Pediatr Dent 15(1):20-24.

Gregory SG, Conelly JJ, Towers AJ, Johnson J, Biscoho D, Markunas CA, Lintas C, Abraspm RL. Wright HH, Ellin P, et al. (2009). Genomic and epigenetic evidence for oxytocin receptor deficiency in autism. BMC Med 7:62. Oct 22.

Guastella AJ, Howard AL, Dadds MR, Mitchell P, Carson DS (2009). A randomized controlled trial of intranasal oxytocin as an adjunct to exposure therapy for social anxiety disorder. Psychoneuroendocrinology 34(6):917-923

Guastella AJ, Einfled SL, Gray KM, Rinehart NJ, Tonge BJ, Lambert TJ, Hicle IB (2012). Intranasal oxytocin improves emotion recognition for youth with autism spectrum disorders. Biol Psychiatry 67(7):692-694.

Guastella AJ, Gray KM, Rinehart NJ, Alvares GA, Tonge BJ, Hickle IB, Keating CM, Cacciotti-Saija C, Einfeld SL (2014). The effects of a course of intranasal oxytocin on social behaviors in youth diagnosed with autism spectrum disorders: a randomized controlled trial. J Child Psychol Psychiatry. Aug 2; Epub ahead of printing.

Guastella AJ, Hickie IB, McGuinness MM, Otis M, Woods EA, Disinger HM, Chan HK, Chen TF, Banati RB (2013). Recommendations for the standardization of oxytocin nasal administration and guidelines for its reporting in human research. Psychoneuroendocrinology 38(5)612-625.

Guastella AJ, MacLeod C (2012). A critical review of the influence of oxytocin nasal spray on social cognition in humans: evidence and future directions. Horm Behav 61(3):410-418. 
Heim C, Young LJ, Newport DJ, Mietzko T, Miller AH, Nemeroff CB (2008). Lower CSF oxytocin concentration in women with a history of child abuse. Mol Psychiatry 14(10):954-958.

Hrdy, SB (2009). Mothers and others: the evolutionary origins of mutual understanding. Cambridge, MA: Belknap Press, Harvard University Press.

Huffmeijeer R, Alink LR, Tops M, Huffmeijer R, Alink LR, Tops M, Grewen KM, Light KC, Bakermans-Kranenburg MJ, et al. (2012). Salivary levels of oxytocin remain elevated for more than two hours after intranasal oxytocin administration. Neuro Endocrinol. Lett. 33:21-25.

Hurlemann R, Patin A, Onur OA, Cohen MX, Baumgartner T, Metzler S, Dziobek I, Gallinat J, Wagner M, Maier W, et al. (2010). Oxytocin enhances amygdala-dependent, socially reinforced learning and emotional empathy in humans. J Neurosci. 30:49995007.

Jack A, Connelly JJ, Morris JP (2012). DNA methylation of the oxytocin receptor gene predicts neural response to ambiguous social stimuli. Front Hum Neurosci. 6:280.

Jacob S, Brune CW, Carter CS, Leventhal BL, Lord C, Cook, EH (2007). Association of oxytocin receptor gene (OXTR) in Caucasian children and adolescents with autism. Neurosci Lett 417(1):6-9.

Johnson R, Baldwin Jr. DC (1968). Relationship of maternal anxiety to the behavior of young children undergoing dental extraction. J Dent Res 47(5):801-805.

Keverne EB, Curley JP (2008). Epigenetics, brain evolution and behaviour. Front Neuroendocrinol 29:398-412

Koch SB, van Zuiden M, Nawijn L, Frijling JL, Veltman DJ, Olff M (2014). Intranasal oxytocin as strategy for medication-enhanced psychotherapy of PTSD: salience processiona dn fear inhibition processes. Psychoneuroendocrinology 40:242-256.

Kosfeld M, Heinrichs M, Zak PJ, Fischbacher U, Fehr E (2005). Oxytocin increases trust in humans. Nature 435(57042):673-676.

Kumsta R, Hummel E, Chenm FS, Heinrichs M (2013). Epigenetic regulation of the oxytocin receptor gene: implications for behavioral neuroscience. Front Neurosci. 7:83. May 23.

Labuschagne I, Phan KL, Wood A, Angstadt M, Chua P, Heinichs M. Stout JC, Nathan PJ (2010). Oxytocin attenuates amygdala reactivity to fear in generalized social anxiety disorder. Neuropsychopharmacology 35(12):2403-13. 
Lee HJ, Macbeth AH, Pagani JH, Young $3^{\text {rd }}$ WS (2009). Oxytocin: the great facilitator of life. Prog Neurobiol 88(2):127-51.

Luo S, Ma Y, Li B, Wang C, Shi Z, Li X, Zhang W, Rao Y, Han S (2015). Interaction between oxytocin receptor polymorphism and interdependent culture values on human empathy. Soc Cogn Afect Neurosci. Feb 13. Epu ahead of print.

McCarthy MM, Crews D (2008). Epigenetics - new frontier in neuroendocrinology. Front Neuroendocrinlo 29(3):341-343.

Miller L, Kramer R, Warner V, Wickramaratne P, Weissman M (1997). Intergenerational Transmission of parental bonding among women. J Am Acad Child Adolesc Psychiatry 36:1134-9.

Nash DA (2010). Ethics, empathy, and the education of dentists. J Dent Educ 74(6):567578.

Puglia MH, Lillard TS, Morris JP, Connelly JJ (2015). Epigenetic modification of the oxytocin receptor gene influences the perception of anger and fear in the human brain. Proc Natl Acad Sci USA. Feb 9, Epub ahead of print.

Rash JA, Aquirre-Camacho A, Campbell TS (2014). Oxytocin and pain: a systematic review and synthesis of findings. Clin J Pain. 30(5):453-462.

Rodrigues SM, Saslow LR, Garcia N, John OP, Keltner D (2009). Oxytocin receptor genetic variation relates to empathy and stress reactivity in humans. Proc Natl Acad Sci USA. 106(50):21437-41.

Simeon D, Bartz J, Hamilton H, Crystal S, Braun A, Ketay S, Hollander E (2011). Oxytocin administration attenuates stress reactivity inborderline personality disorder: a pilot study. Psychoneuroendocrinology 36(9):1418-1421

Strathearn L (2011). Maternal neglect: oxytocin, dopamine and the neurobiology of attachment. J Neuroendocrinol 23(11):1054-65.

Uvnäs-Moberg K, Handlin L, Petersson M (2015). Self-soothing behaviors with particulare reference to oxytocin release induced by non-noxious sensory stimulation. Front Psychol 5:1529.

Uvnäs-Moberg K (2003). The oxytocin factor: tapping the hormone of calm, love, and healing. Translated by Roberta W. Francis. Cambridge, MA: De Capo Press.

Uzefovsky F, Shalex I, Israel S, Edelman S, Raz Y, Mankuta D, Knafo-Noam A, Ebstein RP (2015). Oxytocin receptor and vasopressin receptor 1a genes are respectively associated with emotional and cognitive empathy. Horm Behav 67:60-5. 
Wismer Fries AB, Ziegler TE, Kurian JR, Jacoris S, Pollak SD (2005). Early experience in humans is associated with changes in neuropeptides critical for regulating social behavior. Proc Natl Acad Sci USA 102(47):17237-40.

Weaver ICG (2007). Epigenetic programming by maternal behavior and pharmacological intervention. nature versus nurture: let's call the whole thing off. Epigenetics 2(1):22-8.

Welch, M (2015). Combined oxytocin and secretin treatment for dry eyes and dry mouth. Technology \#cu13261. Columbia Technology Ventures. Accessed July 7, 2015 at www.innovation.columbia.edu/technologies

Zak PJ, Kurzban R, Matzner WT (2004). The neurobiology of trust. Ann. N Y Acad Sci 1032:224-7.

Zak, PJ (2012). The moral molecule: how trust works. Penguin Group. New York.

Ziegler C, Dannlowski U, Bräuer D, Stevens S, Laeger I, Wittmann H, Kugel H, Dobel C, Hurlemann R, Reif A, et al. (2015). Oxytocin receptor gene methylation: converging multilevel evidence for a role in social anxiety. Neuropsychophamacology January 7; Epub ahead of print. 